УДК 342.98:35.082(477)

DOI https://doi.org/10.32837/pyuv.v2i4(29).429

\author{
Н. С. Панова \\ orcid.org/0000-0001-9139-3580 \\ кандидат юридичних наук, \\ доцент кафедри конституційного, адліністративного і міжнародного права \\ Київського інституту інтелектуальної власності і права \\ Національного університету "Одеська юридична академія»
}

\title{
ЗАБЕЗПЕЧЕННЯ СЛУЖБОВОЇ ДИСЦИПЛІНИ В ДЕРЖАВНІЙ СЛУЖБІ
}

Однією з необхідних умов якісного функціонування державної служби в умовах реформування діючої управлінської системи є неухильне додержання державними службовцями порядку проходження служби. Сучасний стан розвитку української державності, що наразі знаходиться в складних соціально-економічних умовах, політичні перетворення, курс на подальшу демократизацію суспільства потребують впровадження дієвих механізмів забезпечення службової дисципліни. Створення умов, за яких державний службовець матиме змогу повною мірою виконувати покладені на нього обов'язки є важливим складником його правового статусу з огляду на актуальність забезпечення прав і свобод громадян.

Попри те, що забезпечення дисципліни в службових відносинах є надзвичайно важливим та актуальним, у теорії адміністративного права йому не приділялося належної уваги. Навіть більше, це питання практично не досліджувалося у контексті тих змін, які протягом останніх років торкнулися інституту державної служби. Окремі аспекти наслідків порушення дисципліни в державній службі розкрито у працях таких вчених, як А.В. Андрушко [1], Д.Н. Бахрах [2], І.О. Картузова [3], Л.М. Корнута [4], О.В. Кузьменко [5], О.Д. Новак [6], М.І. Хавронюк [7], В.І.Щербина [8] та ряду інших. Натомість проблематика службової дисципліни у державній службі та шляхи їі забезпечення залишаються малодослідженими.

У тлумачному словнику української мови дисципліна визначається як «чітко встановлений порядок, дотримання якого є обов'язковим для всіх членів певного колективу» [9, с. 758]. Відповідно до української юридичної енциклопедії, дисципліна (лат. “disciplina” - стриманість, строгість) тлумачиться як точне, своєчасне і неухильне дотримання встановлених правовими та іншими соціальними нормами правил поведінки у суспільному і державному житті [10, с. 199]. Схожої точки зору дотримується M.I. Хавронюк, яким дисципліна визначена як становище, за якого усі суб'єкти правовідносин влади і підпорядкування неухильно додержуються порядку і правил, встановлених законами, а також відповідними статутами і положеннями[7, с. 15].
Як соціальне явище дисципліна характеризується двома нерозривно пов'язаними аспектами: суб'єктивним, який полягає у свідомому дотриманні певного порядку суб'єктами суспільних відносин, і об'єктивним, який має вираження у сукупності правил - регуляторів суспільних відносин, дотримання яких є необхідним для існування самого суспільства. Дисципліна як правова категорія формується за активного впливу правових норм, які закріплені в законах та інших нормативних актах. Законність і дисципліна є самостійними, але тісно пов' язаними поняттями. Законність виступає основним, базовим елементом дисципліни, а тому заходи, які використовує держава для зміцнення і забезпечення законності, одночасно сприяють i зміцненню дисципліни

При цьому внутрішній аспект формування дисципліни (самодисципліни) в будь-якому середовищі складається із системи суб'єктивних уявлень індивіда про дисципліну; засвоєння їі правових та моральних вимог; мотивації на дотримання ïï правил; знання цілей і суспільної значимості дисципліни; ідейно-вольових установок, якими визначаються добровільне та ініціативне виконання вимог. Зовнішніми факторами, які впливають на формування дисципліни, є сукупність політичних, економічних, культурних та правових чинників [11, с. 186].

Дисципліна як динамічний складник будь-якої діяльності характеризується такими ознаками: реалізується у визначеній сфері суспільних відносин; має вираження у фактичній поведінці суб'єкта; передбачає визначеність обов'язків суб'єкта; формується на підставі суб'єктивних уявлень про міру належної поведінки; спрямована на впорядкування та узгодженість у визначеній сфері суспільних відносин; дотримання забезпечується сукупністю заходів.

Щодо особливостей дисципліни в державній службі, то засади їі забезпечення передбачено ст.ст. 61-63 Закону України «Про державну службу» [12]. Насамперед слід зазначити, що службова дисципліна в рамках законодавства про державну службу - це неухильне додержання присяги державного службовця, сумлінне виконання ним 
службових обов'язків та правил внутрішнього службового розпорядку.

Проаналізувавши нормативне визначення, можна стверджувати, що поняття «службова дисципліна» тлумачиться у широкому розумінні та у вузькому. Останне співпадає з нормативним закріпленням службової дисципліни. У широкому значенні, під службовою дисципліною розуміється сукупність дій, які спрямовано на: порушення Присяги державного службовця; порушення правил етичної поведінки державних службовців; вияв неповаги до держави, державних символів України, Українського народу; дії, що шкодять авторитету державної служби; невиконання або неналежне виконання посадових обов'язків, актів органів державної влади, наказів (розпоряджень) та доручень керівників, прийнятих у межах їхніх повноважень; недотримання правил внутрішнього службового розпорядку; перевищення службових повноважень, якщо воно не містить складу злочину або адміністративного правопорушення; невиконання вимог щодо політичної неупередженості державного службовця; використання повноважень в особистих (приватних) інтересах або в неправомірних особистих інтересах інших осіб; подання під час вступу на державну службу недостовірної інформації про обставини, що перешкоджають реалізації права на державну службу, а також неподання необхідної інформації про такі обставини, що виникли під час проходження служби; неповідомлення керівникові державної служби про виникнення відносин прямої підпорядкованості між державним службовцем та близькими особами у 15 -денний строк з дня їх виникнення; прогул державного службовця (у тому числі відсутність на службі більше 3 годин протягом робочого дня) без поважних причин; поява державного службовця на службі в нетверезому стані, у стані наркотичного або токсичного сп'яніння; прийняття державним службовцем необгрунтованого рішення, що спричинило порушення цілісності державного або комунального майна, незаконне їх використання або інше заподіяння шкоди державному чи комунальному майну, якщо такі дії не містять складу злочину або адміністративного правопорушення; прийняття державним службовцем рішення, що суперечить закону або висновкам щодо застосування відповідної норми права, викладеним у постановах Верховного Суду України, щодо якого судом винесено окрему ухвалу.

Службова дисципліна на державній службі детермінується через три основних критерії: неухильне додержання присяги державного службовця, сумлінне виконання службових обов'язків, сумлінне дотримання правил внутрішнього службового розпорядку.

Перший критерій Ірунтується на позиції, що присяга - це: а) урочиста офіційна обіцянка додержуватися певних зобов'язань, клятва вірності якій-небудь справі; б) урочиста обіцянка, часто підкріплена згадуванням чогось дорогого, священного для того, хто обіцяє; в) запевнення у правдивості сказаного.

У правовій літературі пропонуються різні підходи щодо юридичного визначення присяги. Так, деякі автори вважають, що присяга це офіційна урочиста обіцянка додержуватися певних зобов'язань, зокрема, на підтвердження правдивості свідчень, вірності тій чи іншій справі, діяти відповідно до конституції тощо. Інші переконані, що присяга - це клятва на вірність конституції та служінню народу, яку в обов'язковому порядку дає посадова особа, яка вступає на високу державну посаду. Наведені приклади свідчать про різні підходи як до визначення сутності присяги, так і до тих наслідків, які пов'язанні з її прийняттям. У зв'язку із цим постає закономірне питання: присяга - це тільки урочиста обіцянка додержуватися певних зобов'язань, чи це - конкретна клятва (зобов'язання) - акт, який породжує юридичні факти? У тому разі, коли чинне законодавство не пов'язує настання певного правового статусу особи із прийняттям присяги, вона відіграє роль тільки урочистої обіцянки, а в разі, коли такий статус набувається тільки за умови прийняття присяги - вона являє собою зобов'язання, яке породжує певні юридичні факти (присяга працівника прокуратури, військова присяга, присяга працівника органів внутрішніх справ тощо).

Ретроспективний аналіз текстів Присяги державного службовця, які закріплено у законодавстві про державну службу, свідчить про певні відмінності між ними, які насамперед стосуються переліку тих обов'язків, які покладають на себе службовці, приймаючи Присягу.

Так, новітніми є такі положення у тексті нової Присяги: а) поважати та охороняти права, свободи і законні інтереси людини і громадянина, честь держави; б) сумлінно виконувати свої службові обов'язки. У тексті Присяги знаходить свій вияв конституційне положення про те, що джерелом влади є народ України і саме йому адресовано Присягу, яку приймає державний службовець: «... вступаю на військову службу і урочисто клянусь народу України завжди бути вірним і відданим йому ...» [13], «Вступаючи на митну службу, урочисто зобов'язуюсь бути відданим Українському народу, справі української державності ...» [14], «... вступаючи на службу до Державної кримінально-виконавчої служби України, клянуся завжди залишатися відданим Українському народові ...» [15], «... вступаючи на службу до Державної служби спеціального зв'язку та захисту інформації України, присягаю завжди залишатися відданим Українському народові ...» [16]. 
Таким чином, вірне служіння (відданість) народові України є визначальним положенням будьякої Присяги в Україні.

Щодо сумлінного виконання службових обов'язків, то це положення уточнено терміном «службові обов'язки», отже, замість положення «виконання своїх обов'язків», передбачено положення «виконання своїх службових обов'язків», тобто має місце суттєва зміна акцентів в обсязі обов'язків державного службовця (основні / службові), яке знаходить відображення у Присязі [12]. Безперечно, така позиція законодавця є досить спірною, оскільки положення «виконання своїх обов'язків» передбачає ті обов'язки, які визначено у ст. 8 Закону України «Про державну службу», тобто - це основні обов'язки, визначені на законодавчому рівні, які стосуються усіх державних службовців незалежно від посади, яку вони заміщують. Водночас положення «виконання своïx службових обов'язків» стосується як основних, передбачених Законом "Про державну службу», так і посадових обов'язків, тобто конкретних обов'язків, які визначаються відповідно до посадових інструкцій (положень), що затверджуються керівником відповідного державного органу.

Тобто службові обов'язки - це сукупність обов'язків державного службовця, яку становлять обов'язки, визначені: а) чинним Законом; б) Правилами внутрішнього службового розпорядку; в) посадою державної служби, тобто посадовою інструкцією.

Щодо сумлінного дотримання правил внутрішнього службового розпорядку. Перш за все слід зазначити, що Правила внутрішнього службового розпорядку у державному органі (далі - Правила) - це підзаконні нормативні акти локального характеру, які визначають загальні положення щодо внутрішнього службового розпорядку державного службовця: початок та кінець робочого часу державного службовця; перерви, що надаються для відпочинку та прийняття їжі; умови i порядок перебування державного службовця в державному органі у вихідні, святкові та неробочі дні, а також після закінчення робочого часу; порядок доведення до відома державного службовця нормативно-правових актів, наказів (розпоряджень) та доручень із службових питань; загальні інструкції з охорони праці та протипожежної безпеки, загальні правила етичної поведінки в державному органі; порядок повідомлення державним службовцем про його відсутність на службі; порядок прийняття та передачі діловодства (справ) і майна державним службовцем [17]. Також у Правилах, які розробляються у державному органі на основі Типових правил внутрішнього службового розпорядку, можуть передбачатися й інші положення, які не суперечать закону та іншим нормативно-правим актам (щодо порядку надання відпусток, вимоги щодо зовнішнього виду державного службовця тощо).

Аналіз чинного Закону дає підстави стверджувати, що основними напрямами забезпечення службової дисципліни є:

1) дотримання у службовій діяльності вимог Закону України «Про державну службу» [12] та інших нормативно-правових актів у сфері державної служби (Законів «Про запобігання корупції» [18], «Про очищення влади» [19] тощо; Постанов КМУ, наказів НАДС та інших органів виконавчої влади) та виконання правил внутрішнього службового розпорядку;

2) формування керівником державної служби у підпорядкованих державних службовців високих професійних якостей, сумлінного ставлення до виконання своїх посадових обов'язків (тобто своєчасне, точне, інтенсивне, ефективне, творче та ініціативне виконання покладених завдань), поваги до прав і свобод людини і громадянина, їхньої честі та гідності, а також до держави, державних символів України (тобто до визначених і закріплених на конституційно-правовому рівні офіційних знаків держави, які в лаконічній формі відображають її суверенітет та ідеологію і зазвичай мають етнічно-національне походження);

3) поєднання керівниками усіх рівнів методів переконання, виховання і заохочення (ст. 53 Закону України «Про державну службу») із заходами дисциплінарної відповідальності (ст. 66 Закону України «Про державну службу») щодо підпорядкованих державних службовців. При цьому слід зазначити, що це завдання покладається на керівників усіх без винятку рівнів;

4) поєднання повсякденної вимогливості керівників до підпорядкованих державних службовців із постійною турботою про них, виявлення поваги до їхньої честі та гідності, забезпечення гуманізму та справедливості.

Забезпечення службової дисципліни у державній службі, з одного боку, покладається на керівника державної служби, а 3 іншого - на самого державного службовця.

Відповідно, забезпечення службової дисципліни державним службовцем проявляється у сукупності таких зобов'язань:

1) виконання обов'язків, які опосередковано правовим статусом державного службовця (перелік закріплено ст. 8 Закону України «Про державну службу»);

2) недопущення вчинків, несумісних із статусом державного службовця (у цьому контексті поняття «правовий статус державного службовця» слід розглядати як систему його прав, обов'язків, правообмежень);

3) виявлення високого рівня культури (етикет, правила поведінки у громадських місцях, культура спілкування тощо); професіоналізму; витримки 
(здатність державного службовця володіти собою, контролювати свої вчинки та слова) і тактовності (володіння почуттям міри, здатність об'єктивно та стримано оцінювати конкретну ситуацію); поваги (шанобливе ставлення) до громадян, керівництва та інших державних службовців;

4) дбайливого ставлення до державного майна та інших публічних ресурсів (у цьому разі йдеться про бережливе та раціональне використовування державного майна та інших публічних ресурсів (землі, її надр, атмосферного повітря, водних, лісових ресурсів тощо) [12].

Крім того, державний службовець має особисто виконувати покладені на нього посадові обов'язки. Йдеться насамперед про те, що саме державний службовець повинен реалізовувати обов'язки, визначені для нього посадовою інструкцією (положенням) і він не має право передоручати таке виконання іншим особам.

Забезпечення службової дисципліни керівником державної служби проявляється у сукупності наступних зобов'язань:

1) здійснення повноваження щодо притягнення державних службовців до дисциплінарної відповідальності;

2) створення умов для виконання державними службовцями своїх посадових обов'язків і підвищення ними професійної компетентності, вимагання належного виконання посадових обов'язків;

3) здійснення постійного контролю за виконанням державними службовцями посадових обов'язків через перевірку змісту рішень, програм, інших документів (чи їх проектів), що розробляються державними службовцями відповідно до своїх посадових обов'язків; здійснення щорічного оцінювання результатів службової діяльності державних службовців;

4) під час виконання посадових обов'язків керувати винятково публічними інтересами, суворо дотримуватися і забезпечувати дотримання Конституції, законів України та інших нормативно-правових актів, чітко формулювати накази (розпорядження) та доручення, перевіряти точність і своєчасність їх виконання.

5) забезпечення виконання державними службовцями своїх посадових обов'язків, у тому числі шляхом застосування дисциплінарних стягнень (керівник державної служби зобов'язаний не тільки здійснювати контроль за виконанням державними службовцями своїх посадових обов'язків, але й забезпечувати ними таке виконання. При цьому слід зазначити, що це положення за своїм змістом є комплексним, оскільки містить ряд елементів щодо створення належних умов державним службовцям для: виконання своїх посадових обов'язків; підвищення рівня професійної компетентності; реалізації сумлінного, творчого, ініціативного ставлення до своєї службової діяльності);
6) організація роботи державних службовців належним чином, що має вираз у створенні належних умов, встановленні оптимального режиму служби тощо, що має безпосередній вплив на ефективність та результативність їхньої діяльності та забезпечення ефективного виконання завдань, що поставлені перед державним органом;

7) виховування у державних службовців сумлінного ставлення до служби, бережливого ставлення до державного майна, підтримка їхньої ініціативи, а також вжиття заходів щодо додержання ними правил етичної поведінки (така діяльність може мати прояв у: співбесіді; поєднанні різних методів впливу на державного службовця; визначенні пріоритетів службової поведінки тощо);

8) забезпечення прозорості та об'єктивності під час оцінювання результатів службової діяльності державних службовців;

9) організація проведення з державними службовцями профілактичних заходів щодо запобігання вчиненню ними дисциплінарних проступків, виявлення та своєчасне припинення їх вчинення [12]. При цьому до профілактичних заходів слід віднести: ознайомлення їх із Загальними правилами етичної поведінки державних службовців [20], ознайомлення їх із Правилами внутрішнього службового розпорядку [17], проведення семінарів, тренінгів із зазначених питань; усунення умов та причин вчинення дисциплінарних проступків тощо.

Безпосередній керівник державного службовця має право вносити клопотання керівникові державної служби про притягнення державного службовця до дисциплінарної відповідальності за вчинення дисциплінарного проступку [12]. При цьому важливо зазначити, що безпосередній керівник «має право», а не зобов'язаний вносити таке клопотання, тобто це є його правом, а не обов' язком. За своїм змістом це положення кореспондується із положенням п. 3 ч. 1 ст. 61 цього Закону: поєднання методів переконання і виховання із заходами дисциплінарної відповідальності щодо підпорядкованих державних службовців. Уявляється, що такий підхід є цілком правомірним, оскільки надає безпосередньому керівникові можливість застосовувати різні методи державного управління у кожній конкретній ситуації.

За невиконання зобов'язань щодо забезпечення службової дисципліни на державній службі до державного службовця та до керівника державної служби застосовуються відповідні заходи відповідальності згідно із законом. Так, підставою притягнення до відповідальності керівника державної служби є:

- невжиття ним заходів щодо притягнення підпорядкованого йому державного службовця до дисциплінарної відповідальності за вчинений 
дисциплінарний проступок, що має прояв у: відсутності ініціювання службового розслідування у разі встановлення факту, який за попередньою оцінкою є дисциплінарним проступком державного службовця; відсутності утворення дисциплінарної комісії, або незабезпечення належних умов для її роботи або втручання у їі діяльність; відсутності прийняття рішення про накладення на державного службовця дисциплінарного стягнення у разі встановлення в діянні державного службовця дисциплінарного проступку;

- неподання матеріалів щодо вчинення державним службовцем адміністративного проступку, корупційного або пов'язаного з корупцією правопорушення, злочину до органу, уповноваженого розглядати справи про такі правопорушення, що має наслідком притягнення керівника державної служби, окрім дисциплінарної відповідальності, до адміністративної відповідальності, яку передбачено ст. $172^{2}$ КУпАП [21].

Таким чином, слід зазначити, що забезпечення службової дисципліни у державній службі реалізується через сукупність інструментів впливу на усіх учасників службових відносин - і на керівника державної служби, і на державного службовця. Досягнення належного рівня службової дисципліни сприятиме дотриманню принципів державної служби, зокрема, принципів верховенства права, об'єктивності, професіоналізму, ефективності, особистої відповідальності і ряду інших. Вбачається доцільним подальше дослідження інструментів забезпечення службової дисципліни у державній службі.

\section{Jimepamypa}

1. Андрушко А.В. Дисциплінарний проступок як підстава дисциплінарної відповідальності. Держава і право. 2008. Вип. 41. С. 380-385.

2. Бахрах Д.Н. Особенности дисциплинарной ответственности как вида юридической ответственности. Совреленное право. 2008.№ 10. С. 40-41.

3. Картузова И.О. Дисциплинарная ответственность государственных служащих : дис. канд. юрид. наук ; Одесская гос. юрид. академия. Одесса, 1999. 196 с.

4. Корнута Л.М. Загальні правові засади дисциплінарної відповідальності державних службовців в Україні. Митна справа. 2012. № 2 (80). Ч. 2. К. 2. С. 70-75.

5. Кузьменко О.В. Місце дисциплінарних проваджень в адміністративно-процесуальному праві. Вісник Львівського ін-ту внутрішніх справ. 2003. № 2. С. 109-119.

6. Новак О.Д. Дисциплінарний проступок як підстава дисциплінарної відповідальності державних службовців. Часопис Київського ун-ту права. 2012. № 2. C. 129-133.

7. Хавронюк М.I. Дисциплінарні правопорушення і дисциплінарна відповідальність : навч. посіб. Київ : Атіка, 2003. 240 с.

8. Щербина В.I. Дисциплінарна відповідальність державних службовців органів внутрішніх справ : дис. ... канд. юрид. наук . Харків, 1998. 208 с.

9. Новий тлумачний словник української мови : у 4-х т. / уклад. В.В. Ярошенко, О.М. Сліпушко. Київ : Аконіт, 1998. Т. 1. С. 758.
10. Юридична енциклопедія: в 6 т. / редкол. : Ю.С. Шемшученко (голова редкол.) та ін. Київ : «Укр. енцикл.», 1998.

11. Афанасьєвь К.К. Дисципліна як важливий чинник забезпечення правопорядку. Сучасний правопорядок: національний, інтегративний та міжнародний виміри : тези міжнар. наук.-практ. конф., 1314 черв. 2008 р. Одеса : Фенікс, 2008. С. 185-187.

12. Про державну службу : Закон України від 10.12.2015 p. Дата оновлення: 01.01.2020 p. URL: https://zakon.rada.gov.ua/laws/show/889-19.

13. Про текст Військової присяги : Постанова ВРУ від 06.12.1991 р. Дата оновлення: 06.12.1991 p. URL: https://zakon2.rada.gov.ua/laws/show/193612 ;?lang $=\mathrm{ru}$.

14. Митний кодекс України: Закон України від 13.03.2012 р. Дата оновлення: 13.02 .2020 р. URL:https://zakon.rada.gov.ua/laws/show/4495-17.

15. Про Державну кримінально-виконавчу службу України: Закон України від 23.06.2005 р. Дата оновлення: 01.01.2020 p. URL: https://zakon.rada.gov.ua/ laws/show/2713-15.

16. Про Державну службу спеціального зв'язку та захисту інформації України : Закон України від 23.02.2006 p. Дата оновлення:02.01.2020 p. URL: https://zakon.rada.gov.ua/laws/show/3475-15.

17. Про затвердження Типових правил внутрішнього службового розпорядку: Наказ НАДС від 03.03.2016 № 50. Дата оновлення: 03.03.2016 p. URL: https://zakon.rada.gov.ua/laws/show/z0457-16.

18. Про запобігання корупції: Закон України від 14.10.2014 p. Дата оновлення: 18.10 .2019 p. URL: https://zakon.rada.gov.ua/laws/show/1700-18.

19. Про очищення влади: Закон України від 16.09.2014 p. Дата оновлення: 25.09.2019 p. URL: https://zakon.rada.gov.ua/laws/show/1682-18.

20. Про затвердження Загальних правил етичної поведінки державних службовців та посадових осіб місцевого самоврядування: Наказ НАДС від 05.08.2016. № 158. Дата оновлення: 27.09.2016. URL: https://zakon.rada.gov.ua/laws/show/z1203-16.

21. Кодекс України про адміністративні правопорушення від 07.12.1984 р. Дата оновлення: 02.10.2019 р. URL: https://zakon.rada.gov.ua/laws/show/80731-10.

\section{Анотація}

Панова Н. С. Забезпечення службової дисципліни в державній службі. - Стаття.

У статті проаналізовано основні чинники забезпечення службової дисципліни в державній службі: нормативно-правове забезпечення службової дисципліни, чинники формування архетипу дисциплінованої поведінки, зобов'язання державних службовців та керівників державної служби щодо підтримки службової дисципліни.

Запропоновано тлумачити поняття «службова дисципліна у державній службі» 3 позиції вузького підходу, який кореспондує з нормативним закріпленням поняття, та широкого підходу, який пов'язаний з трактуванням поняття через сукупність дій, які спрямовано на: порушення Присяги державного службовця, порушення правил етичної поведінки державних службовців, вияв неповаги до держави, державних символів України, Українського народу, невиконання або неналежне виконання посадових обов'язків, актів органів державної влади, наказів (розпоряджень) та доручень керівників, прийнятих у межах їхніх повноважень, недотримання правил внутрішнього службового розпорядку, перевищення службових повноважень, якщо 
воно не містить складу злочину або адміністративного правопорушення, невиконання вимог щодо політичної неупередженості державного службовця тощо.

Визначено, що службова дисципліна у державній службі детермінується через основні критерії неухильного додержання присяги державного службовця, сумлінного виконання службових обов'язків, сумлінного дотримання правил внутрішнього службового розпорядку. До основних напрямів забезпечення службової дисципліни у державній службі віднесено: дотримання у службовій діяльності вимог законодавства про державну службу, формування керівником державної служби у підпорядкованих державних службовців високих професійних якостей, сумлінного ставлення до виконання своїх посадових обов'язків, поєднання керівниками усіх рівнів методів переконання, виховання і заохочення із заходами дисциплінарної відповідальності щодо підпорядкованих державних службовців, поєднання повсякденної вимогливості керівників до підпорядкованих державних службовців із постійною турботою про них, виявлення поваги до їхньої честі та гідності, забезпечення гуманізму та справедливості.

Ключові слова: службова дисципліна, дотримання Присяги, сумлінне виконання службових обов'язків, правила внутрішнього службового розпорядку, керівник державної служби.

\section{Summary}

Panova N. S. Provision of official discipline in the civil service. - Article.

The article analyses the main factors of ensuring official discipline in the civil service: statutory regulation of professional discipline, factors of formation of the archetype of disciplined behavior, obligations of civil servants and heads of civil service offices to support of official discipline.
It is proposed to interpret the concept "official discipline" from the perspective of a narrow approach, which corresponds to the statutory consolidation of the concept and the broad approach that is associated with the interpretation of the concept through a set of actions aimed at violating the oath of a civil servant, neglecting the rules of ethical conduct of civil servants, manifesting disrespect for the state, national symbols of Ukraine, the Ukrainian people, failure to perform or improper performing of official duties, acts of state authorities, orders (decrees) and the instructions of the leaders adopted within their powers, non-compliance with the rules of internal service, abusing of power if it does not contain components of crime or administrative offense, failure to comply with the requirements of political impartiality of a civil servant, etc.

The author marks that official discipline in the civil service is determined through the basic criteria of steadfast adherence to the oath of a civil servant, faithful performance of duties, honest compliance with the rules of an internal official order. The main areas of the official discipline in the civil service include: compliance with the requirements for civil service legislation in the professional activity, the formation of high professional qualities of subordinate civil servants by the head of the civil servant, conscientious attitude to the discharge of their official duties, the combination of methods of persuasion, education and encouragement with measures of disciplinary responsibility towards subordinate public servants by leaders of all levels, a combination of leaders' exacting attitude towards subordinates subordinate civil servants with constant concern for them, manifestation of respect for their honor and dignity, guarantee of humanism and justice.

Key words: official discipline, compliance with oath, honest performance of official duties, rules of internal official order, head of civil service. 